12.Ладченко М. М. До проблеми збагачення словникового складу німецької розмовної мови. Таврійські філологічні наукові читання: матеріали міжнародної наук.-практ. Конф. (Київ, 27-28 січня 2017 р.) Київ: Таврійський національний університет імені В. І. Вернадського, 2017. С. $99-103$.

13.Мюллер В. Великий німецько-український словник. К.: Чумацький шлях, 2005. $792 \mathrm{c}$.

14.Перестюк Т. Аугментативні похідні із зоосемічним компонентом у німецькій мові. URL: https:// old.lingua.lnu.edu.ua/ Foreign_Philology _120/articles/11\% 20 perestiuk\%20vypravleno\%20formatted.pdf (дата звернення 18. 06. 2020).

15.Ходаковська Н.Г. Семантичний та прагматичний аспекти стилістично маркованих похідних іменників сучасної німецької мови. URL: https:// mydisser.com/ua/catalog /view /312/771/22044.html (дата звернення 15. 10. 2019).

УДК $811.111+81^{\prime} 42$

DOI: $10.24144 / 2617-3921.2020 .18 .80-90$

Антоніна Марковська кандидат філологічних наук, дочент кафедри іноземних мов Миколаївський національний аграрний університет, orcid.org/0000-0003-1598-7517 м. Миколаїв, Україна $+38(066) 4907450$ markovska@mnau.edu.ua Ольга Саламатіна кандидат філологічних наук, дочент кафедри іноземних мов Миколаӥвський національний аграрний університет, orcid.org/0000-0002-1457-2822 м. Миколаїв, Україна $+38(066) 3369027$ salamatina@mnau.edu.ua

\title{
Functional features of the modern foreign publicistic interview
}

Анотація. Стаття присвячена розкриттю понять «функиіональна прагмалінгвістика», «функиіональний стиль» та виділенню їхніх важливих рис. Виявлено, щзо міждисциплінарний підхід до тексту як до інструменту та продукту пізнавально-комунікативної діяльності, що відбувається у проиесі відображення реальності суб'єктами пізнання, стає все більш актуальним. 
Текст розглядається не лише як навчальний матеріал, а й як його предмет. Дискурс реальної розмови інтерв 'юера та респондента призводить до появи специфічного інтерв'ю, яке характеризується смисловою єдністю, комунікативною важливістю та виконує ряд функиій. 3 визначення «функиїі» як призначення певного об'єкту встановлено, що необхідно розрізняти функиії елементів мови та функиії мовленнєвих творів. Проаналізовано специфіку функиій публіцистичного інтерв'ю, щзо залежить від ситуачії, комунікативних завдань і прагматичної мети його авторів, на матеріалі сучасної англомовної та німецькомовної преси. Визначені і охарактеризовані спечифічні функиіі інтерв'ю - інформування та впливу. 3'ясовано, щьо публіцист запевняє шляхом емоційного впливу на читача і тому в явній формі виражає своє ставлення до повідомлюваного. Вимога впливати на масового читача створює таку специфічну особливість сучасного журналістського тексту, як його виразність. Вимога до швидкості передачі інформації та ї̈ суспільної важливості створює таку особливість, як нейтралітет чи стандарт. Стандартизачія виявляється у підборі стилістичних засобів різного рівня: лексичних, морфологічних, синтаксичних, образних, графічних, які характерні для текстів иъього типу. Виразність стилістичних засобів дає можливість передати емоційний, конотативний та очіночний аспект подій та фактів, відображених у пресі. Виділено важливість діалектичної єдності стандарту та експресї в текстах сучасних іншомовних інтерв'ю преси. 3'ясовано, що вона зумовлена не лише необхідністю передачі певної інформації масовому читачеві, а також потребою автора досягти певного прагматичного ефекту або кінцевої мети, що призводить до зміни соціальної діяльності адресата. Встановлено, що у механізмах реалізаиії основної функиії текстів інтерв'ю, окрім експресивності, задіяні такі найважливіші мовні категорії, як емотивність, оцінність та модальність.

Ключові слова: функиіональна прагмалінгвістика, функиіональний стиль, денотативна функція, експресивність, емотивність, стандарт.

Abstract. The article is devoted to the disclosure of the concepts "functional pragmatic linguistics", "functional style" and highlighting their important features. It has been revealed, that an interdisciplinary approach to the text as the instrument and product of cognitive-communicative activity that takes place in the process of reality reflection by the cognition subjects is becoming more relevant. The text is considered not only as a study material but also as its subject. The discourse of interviewer's and respondent's real conversations leads to the emergence of a specific interview, characterized by semantic unity, communicative importance, and performs a number of functions. The peculiarities of the functions of a journalistic interview, depending on the situation, communicative tasks and pragmatic purpose of its authors, are analyzed on the material of the modern English and Germanlanguage press. Specific interview functions - informing and influencing - have been identified and characterized. The requirement to influence the mass reader creates 
such a specific feature of modern journalistic text as its expressive nature, and the requirement for the speed of information transmission and its socially importance creates such a feature as neutrality or standard. Standardization is manifested in the selection of stylistic means of different levels: lexical, morphological, syntactic, figurative, graphic, which are typical for the texts of this type. The expressiveness of the stylistic means makes it possible to convey the emotional, connotative, and evaluative aspect of the events and facts reflected in the press. The importance of dialectical unity of standard and expression in the texts of modern foreign language press interviews is emphasized. It is revealed that it is caused not only by the need to convey certain information to the mass reader, but also by the author's need to achieve a certain pragmatic effect or end goal, which leads to a change in the social activity of the addressee.

Keywords: functional pragmalinguistics, functional style, denotative function, expressiveness, emotionality, standard.

Introduction. One of the main distinctive features of the linguistic development of science in the late twentieth - early twenty-first centuries is the implementation of a functional paradigm of linguistic researches, focused on the study of language in action, in real communicative acts $[16$, p. 1]. The main and primary object and material of linguistic researches was the text from which various data on the structure of language, its system-structural parameters, the taxonomy of linguistic units were taken, but nowadays an interdisciplinary approach to the text as the instrument and product of cognitive-communicative activity that takes place in the process of reality reflection by the cognition subjects is becoming more relevant; the text is considered not only as a study material but also as its subject. Functionalpragmatic paradigm, in which, as noted by the outstanding Russian linguist A.G. Baranov, is the most consistent with this guideline, the problems of language learning in action are brought to the fore and text in dynamics becomes the main unit of research [6, p. 3]. Thus, A.G. Baranov defines functional pragmalinguistics as a complete semiotics, the subject of which is the text in its dynamics, correlated with the main subjects, with the "ego" of the author and recipient, who create the text $[5$, p. 9]. This definition of pragmatics underlies linguistic research on the subjectivity of language, which provides it with an adequate fulfillment of its main function - to be a means of communication. As you know, the discourse of interviewer's and respondent's real conversations leads to the emergence of a specific interview, characterized by semantic unity and communicative importance, and performs a number of functions. Nowadays in spite of different linguistic researches of separate features in publicistic interview the problem of analysis of functional specificity of the modern foreign interview in press taking into account its communicative and pragmatic signs, remains unresolved. This fact stipulated the choice of theme of this work. 
The objectives of the article are: to analyze functional specificity of the modern interview in the foreign press, to determine and characterize its specific functions, aimed at realizing communicative intentions and pragmatic objectives.

Methods. The material of the research is the 500 texts of the English-language and German-language press, which were extracted by continuous selection. The study used the following methods and techniques of analysis in a complex combination: the method of linguistic observation and pragmasemantic method made it possible to outline the features of functional style in general, to determine peculiarities of the functions of a modern foreign journalistic interview, depending on the situation, communicative tasks and pragmatic purpose of its authors; quantitative analysis was used to calculate the dominant features of the interview texts.

Results and Discussion. Ukrainian researcher O.I. Myholinets calls an important feature of the functional-pragmatic scientific paradigm the targeted communication orientation, which has a significant impact on both the structure of the text and its components [16, p. 1].

Purposefulness as an integral feature of speech activity forces the author of a journalistic interview to consider the potentialities of linguistic units for the fullest expression of his intentions, the possibility of their adequate interaction within the framework of utterance, and both structural and functional characteristics of linguistic units are equally important. The function of linguistic means is interpreted by L.I. Pavlenko as the ability to fulfill a certain purpose and proper functioning in speech; at the same time, function is the result of functioning, that is, a fulfilled purpose, aim achieved in the speech [19, p. 14]. It is known that the term "function" is taken from mathematics and logic. This term is used by linguists in two meanings: as a "role, task" in the target language model put forward by the Prague Linguistic Circle in the 1920's, and as a "creation of two variables" [17, p. 8].

In A.G. Baran's concept, function means the pragmatic orientation of the interview text as an element of communication. It is directed at the reader - his will, intelligence, emotions, and comes from the author of the interview as his intention [6, p. 162]. E. Grosse, on the other hand, insists on the distinction between the concepts and, accordingly, the terms "function of the text" and "intension of the text". According to the linguist, the function of the text is information for the recipient: how he or she should perceive the text (for example, as informative or as stimulating), and the intention should be hidden and not correspond to the function of the text [28, p. 131-132].

For some other scientists, the concept of "function" was identical to the concept of "purpose". For example, I.G. Timakova considers function as the purpose of a particular element, an object [24, p. 13], although, according to some researchers, there is a fundamental difference between function and purpose $[6$, p. $164 ; 17$, p. 8].

By "purpose" they mean a pre-planned result of the individual's or team's conscious activity, and the term "function" is defined primarily as the purpose of an object in some system. Linguists point out that this view does not contradict the 
function as a relation, since the purpose can be called a special case of a relation [17, p. 8]. However, scientists note that the function-relation is a reflection of the general connection and interdependence of any objects and phenomena of the real world, and the function-purpose is possible only for artificial objects created by a person for a specific purpose, and in which the results of purposeful human activity are "reflected" [17, p. 8-9]. Language as an artificial formation has not only functionsrelations, entering into endless multifaceted connections with the world of people and objective reality, but also functions-purposes: cognitive and communicative, in addition, the second function is considered a priority [17, p. 9]. Based on these two functions, depending on the specific socio-historical conditions for the existence of a particular language, additional functions and means of their realization emerge in it. They usually include: nominative function (names of phenomena and objects of reality); informative (provides factual information); orientative (facilitates quick search for information); predictive (predicts the content of the next text); punctuation (promotes the separation of one text from another); emotional (conveys a sense of speech); voluntary (expresses will, drives the addressee to action); expressive-appeal (attracts the recipient's attention, prompts him to perceive the message); attractive (attracts the addressee's attention); phatic (encourages the addressee's interest); influence function (assures the addressee); advertising function (attracts the addressee); contact initiative (promotes social etiquette); aesthetic function (affects the aesthetic sense of the addressee) etc. [29, p. 355]. Thus, from the definition of function as the purpose of a particular object in this system, it follows that it is necessary to distinguish between the functions of speech elements and the functions of speech works (expressions, texts) [17, p. 9]. The functions of language elements, as noted above, are determined by their function in forming a speech utterance with a certain pragmatic orientation, that is, in "linguistic reality". Elements of language - phonemes, morphemes, words, sentences, in addition to the basic functions cognitive and nominative - also perform an integrative function, since each lowerlevel unit is part of a higher-level unit [17, p. 9]. The functions of speech works texts, utterances are determined by their relation to objective reality. These units can have role functions in addition to relationship functions. The same utterance (text) in different situations can play different roles, have different content, serve as a means of achieving different pragmatic goals, and conversely, different utterances (texts) can serve as a means of achieving the same goal [17, p. 9]. Of course, the purpose of communication is always to convey information. However, any act of communication is not just a transfer of information, because its occurrence is always conditioned by the need for the speaker to achieve a certain pragmatic effect or end goal, to change somehow the physical, spiritual, emotional state of the addressee or addressees. Achieving this result is possible only through the purposeful selection and use of all the variety of means possessed by the system of a certain language, not only certain stylistic means, but also all graphic, phonetic, lexical, grammatical and syntactic means of language [17, p. 10]. 
According to the definition of linguists, the means of implementing the basic (communicative and cognitive) and additional functions of the language, ensuring the effectiveness of the speaker's speech activity, are the subject of functional stylistics [17, p. 10]. It is haracterized as a science that studies the communicative and nominative resources of the linguistic system and the principles of the selection, use of linguistic means to convey thoughts and feelings in order to achieve certain pragmatic results in different conditions of communication [13, p. 49]. As I.V. Arnold notes, stylistics considers the units of all language levels from a functional point of view. It studies the functioning of both the individual elements of the language system and the individual language subsystems (the so-called "functional language styles"), as well as of the entire language system as a whole [2, p. 19].

Scientific study of functional style as the central concept of modern stylistics, which began in the 20's of the twentieth century in the works of scientists from the Prague Linguistic Circle, in the works of M.M. Bakhtin [7], V.V. Vinogradov [9], G.O. Vinokur [10] and later - H.P. Apalat [1], N.D. Babych [3], L.R. Bezuhla [8], T.G. Vinokur [11], M.N. Kozhinoy [13], V.G. Kostomarov [14], T.V. Matveyeva [15], N.M. Rasinkina [20], O.B. Sirotinina [21], G.E. Solganik [22], Yu.S. Stepanov [23], V.A. Chabanenko [26] and others found that functional styles are categories that are objective, historically influenced by the functions required in the communication process.

Interview as one of the most striking and widespread genres of functional style of the press performs a number of functions inherent in journalism: informative, educational, popularizing, educating, organizing, analytical, critical, hedonistic (entertaining) etc. However, its main functions, which absorb all of the above functions and are most directly expressed in the style of speech, are informative and pragmatic, or function of influence on the mass addressee (reader) [13, p. 184].

Analysis of the German-language and English-language publicistic interviews showed that specificity of the informative function, performed by a journalistic interview, can be defined as denotative and shows that the information in this field of social activity is addressed not to a narrow circle of specialists, such as, for example, in the field of science, but to the broad masses, all the speakers; the speed of information transfer is necessary here, which is not necessary, for example, in an official-business style.

The informative function of the journalistic interview is embodied in the features of the journalistic style that are associated with the expression of intellectual intelligence of speech. M.N. Kozhin considers such stylistic features:

1) documentary and factual accuracy of narration is emphasized;

2) restraint, some formality or "neutrality", which emphasize the importance of facts, information;

3) a certain generality and conceptuality of presentation as a result of analyticity and factuality (often together with figurative specificity of expression);

4) argumentation [13, p. 187]). 
Our research showed, that of particular importance is the function of influence, which is defined as pragmatic: if in a scientific style, the author only appeals to the addressee's mind, argues any position through logical arguments or accurate calculations, then the publicist assures by emotional impact on the reader and therefore in explicit form their attitude towards the expressed information. It is also very important that this attitude is not always purely individual, but it is usually an expression of the opinion of a particular social group addressed to the masses.

Thus, the requirement of influencing a mass reader creates such a specific feature of a publicistic interview as its expressive character, and the requirement of the speed of information transmission, and of social importance, creates such a feature as neutrality or standard (term V.G. Kostomarov [14]).

Of course, the standard determines the typicality of organizing press interviews at different levels (lexical, grammatical, stylistic, structural), and expressiveness of journalistic interviews is called an important factor in their pragmatic function realization, since expressive features are ancillary in the implementation of communicative intentions and pragmatic of the interview authors [12, p. 118]. Researchers claim that the implementation of the pragmatic goal of the authors of the interview texts is simplified by the most pronounced pragmatic function of signs of all levels inherent in non-fiction texts of mass communication in general [12, p. 116-127].

The expressiveness of the interview text is understood to mean all language tools used to express clearly the content of the interview and its attitude to the author in order to enhance the influence on the addressee. Indeed, since the interview is addressed to a wide audience, the author is faced with the need to interest the reader not only with the topic of the speech, but also with its language form. This is attributed to the varying degrees of expressive coloring of the speech, which includes the rather subtle appreciation of the colors that accompany the speech, make it distinctive. Expression is invariably accompanied by complications and extensions of the content structure of words and sentences.

V.K. Kharchenko, for example, considers that expression has a dual meaning: expressiveness as a property of language in general and connotative feature in the meaning of the word - in the narrow sense [25, p. 68].

V.I. Shilovsky [27] contrasts expressiveness and emotiveness as two equal but with different semantics components of lexical meaning in a word. However, the researcher's definition of expressiveness as a category that enhances the influence and power of expression, its characterization, and emotiveness as a category related to the feelings is not sufficiently substantiated (in any case, in relation to "expression"). Generalizing about the functionality and emotional content of the term "expression" T.G. Vinokur finds it convenient, because in the expression these two signs are often combined with each other [11, p. 57].

Of course, the fact that newspaper communication is a one-way channel of information transmission (and therefore performs informative function) has never raised any objections. At the same time, the question of the influence function in 
linguistics has long had no clear explanation. A significant contribution to the solution of this problem was made by V.G. Kostomarov [14]. He proposed his approach according to which the language of the press is the dialectical unity of the standard and expression, because in the conditions of newspaper communication, rationalization and attraction to the standard only cannot ensure the process of communication and are inevitably balanced in the organic unity of the desire for expression [14, p. 88].

It is undeniable that emotions are a necessary part of any cognitive process, and therefore interview texts must be equally drawn to the mind and the feelings. In this connection, the concept of V.G. Kostomarov, based on the recognition of the principal role of both mentioned functions of the journalistic text, seems appropriate. The pragmatic function, being equal in relation to the information function, occupies a significant place in mass media communication. One of the main tools for its implementation is expressiveness. In other words, an inclusion ratio is established between expression and impact.

There is a formation of a new function of the language itself - the function of controlling the function of a vast array and collective of people, manipulating their consciousness. It is most clearly implemented in the media. Its existence is justified by the specific objectives of the latter and the fact that the previously planned reaction of the addressee does not include the speech response, and therefore does not correspond to the structure of ordinary speech act. Thus, in recent studies of linguists, one more self-sufficient function of the media is distinguished - control, manipulation. Manipulation refers to the introduction into the addressee's mind of the instructions in the mode of reduced control on his part, which is achieved by specific types of submission of information, which is presented as truth $[4$, p. 5].

Obviously, the implementation of this function largely involves the impact on the individual's cognitive system, taking into account the ways of processing information by a person. Under the influence of the recipient's cognitive system, one must understand the change, transformation (or support) of the personal picture of the world, the construction of one's own conceptual picture - a kind of interpretation of the surrounding reality in basic human ideas. In other words, one picture of the world (more precisely, its fragment) is "translated" into another.

The intensification of expressiveness in the texts of the modern press interviews is primarily due to the task of exercising influence, which is embodied in the expressive presentation of publicistic material. Reality is one of the most important factors affecting the use of expressive means, since the interview is bound to interest the reader, affect his or her feelings. This is explained by the desire of the addressee to emphasize the novelty of the material presented, the desire to interest the potential addressee.

The essential basis for expressiveness of the press interview is communicative and pragmatic conditionality, since the sender of information must be guided by two provisions: 
a) to disclose information "sparingly" and be adequately understood;

b) to influence the recipient of information in emotional and aesthetic sense, purposefully to carry out "communication" with the reader, which is reflected in the relevant organization of the journalistic text [18, p. 96].

The next important point that predetermines the use of expressive means in the interview texts, K.V. Oleksandrenko underlines the nomination of new concepts, phenomena, extraordinary events, facts. Finding the most appropriate expression dictates the ability to use certain linguistic means. Emergency nomination involving imaginative, expressive means ensures the clarity, effectiveness of information in a journalistic text. This is especially true of interview headlines because they inform about events, phenomena, processes and thus have some emotional impact on the recipient. The validity of headings is ensured by the expressiveness of the main part, that is, it can be argued that we are dealing with a type of paralinguistic expressiveness - factual expressiveness [18, p. 97].

In exploring the factors that create the expressiveness of an interview, one should not finally take into account the fact that the process of journalistic creativity is the activity of individuals. Therefore, the use of expressive means in the texts of this genre also depends on the intellectual and emotional state of the communicator.

Conclusions. Summarizing the above, it should be emphasized that in each case, the use of expressive means usually involves the interaction of several of these factors, the exact delineation of which is impossible. In general, the question of the status of expressiveness in a press interview is resolved unambiguously by most linguists - it is an objectively existing phenomenon, which is seen as the primary means of developing journalistic communication. The language of the press is the dialectical unity of the standard and expression, because in the conditions of newspaper communication, rationalization and attraction to the standard only cannot ensure the process of communication and are inevitably balanced in the organic unity of the desire for expression. The pragmatic function, being equal in relation to the information function, occupies a significant place in mass media communication. It should be accentuated that in the mechanisms of realization of the main function in the interview texts, apart from expressiveness, such important language categories as emotion are involved, evaluation and modality, which correlate with one another and exert influence that should change the addressee's psychological state, his knowledge and thoughts, and, finally, social activity. The results of this work can be used for further research in general linguistics on functional and pragmatic features of the texts of different types. 


\section{REFERENCES}

1. Апалат Г. П. Структура, семантика і прагматика текстів інтерв'ю (на матеріалі сучасної англомовної преси) : дис. ... канд. філол. наук : 10.02.04 / Нац. лінгв. ун-т. Київ, 2002. 203 с.

2. Арнольд И. В. Стилистика. Современный английский язык. Москва : Флинта, Наука, 2005. 384 с.

3. Бабич Н. Д. Практична стилістика і культура української мови : навч. посіб. Львів : Світ, 2003. 432 с.

4. Байков В. Г. Манипулятивная семантика и контрпропаганда. Функиионирование языка как средства идеологического воздействия. Краснодар, 1998. С. 5-13.

5. Баранов А. Г. Текст в функцонально-прагматической парадигме : учеб. пособ. / Кубан. гос. ун-т. Краснодар: Кубан. гос. ун-т., 1988. 90 с.

6. Баранов А. Г. Функцонально-прагматическая концепция текста : монография. Ростов н/Д : Рост. ун-т, 1993. 182 с.

7. Бахтин М. М. Проблемы речевых жанров. Литературно-критические статьи. М. : Художественная литература, 1986. С. 428-472.

8. Безугла Л. Р. Дискурс як когнітивно-комунікативний феномен : монографія. Харків : Константа, 2005. 356 с.

9. Виноградов В. В. Проблема авторства и теория стилей : мография. М. : Изд-во худ. лит., 1961. 614 с.

10. Винокур Г. О. Филологические исследования : лингвистика : учеб. пособ. Москва : Наука, 1990. 452 с.

11. Винокур Т. Г. Закономерности стилистического использования языковых единиц : монография. М. : Наука, 1980. 237 с.

12. Кожин А. Н., Крылова О. А., Одинцов В. В. Функциональные типы русской речи: монография / за ред. А. Н. Кожина. Москва : Высшая школа, 2005. 223 c.

13. Кожина М. Н. Стилистика русского языка : монография. М. : Просвещение, 1993. 224 с.

14. Костомаров В. Г. Русский язык на газетной полосе. Некоторые особенности языка современной публіцистики: учеб. пособ / МГУ. Москва : МГУ, 1971. 267 с.

15. Матвеева Т. В. Функциональные стили в аспекте текстовых категорий : синхронно-сопоставительный очерк : монография. Свердловск : Издво Урал. ун-та, 2002. $172 \mathrm{c.}$

16. Миголинець О. І. Функціонально-стильові характеристики префіксальної номінації в сучасній англійській мові : автореф. дис. на здобуття наук. ступеня канд. філол. наук : 10.02.04 / Нац. ун-т ім. Івана Франка. Львів, 2004. 17 с.

17. Мороховский А. Н., Воробьёва О. П., Лихошерст Н. И. Стилистика английского языка : учеб. пособие / за ред. А. Н. Мороховского. К. : Вища школа, 1991. 272 с. 
18. Олександренко К. В. Екстралінгвістичні фактори створення експресивності у газетній комунікації. Актуальні проблеми філології та перекладознавства. Хмельницький : ХНУ, 2007. Вип. 3. С. 94-96.

19. Павленко Л. I. Синтаксичні та функціонально-семантичні характеристики експлікаційних моделей в англійському розмовному мовленні : автореф. дис. на здобуття наук. ступеня канд. філол. наук : 10.02.04 / Нац. ун-т ім. В. Н. Каразіна. Харків, 2004. 18 с.

20. Разинкина Н. М. Функциональная стилистика : учеб. пособ. М. : Высш. шк., 2003. 182 c.

21. Сиротинина О. Б. Межстилевая и внутристилевая вариативность языковой системы. Вопросы стилистики. Саратов : Сарат. ун-т, 1986. Вып. 21. С. 3-8.

22. Солганик Г. Я. Современная публицистическая картина мира. Публицистика и информация в современном обществе. М. : Флинта, Наука, 2000. С. 9-23.

23. Степанов Ю. С. Методы и принципы современной лингвистики : монографія. М. : Наука, 2006. 312 с.

24. Тимакова И.Г. Функционирование эпиграфов в немецкоязычном тексте : автореф. дисс. на соискание уч. степени канд. филол. наук : 10.02.04 / МГУ. М., 2006. 21 c.

25. Харченко В. К. Разграничение оценочности, образности, экспрессии и эмоциональности в семантике слова. РЯШ. 1976. № 3. С. 66-71.

26. Чабаненко В. А. Стилістика експресивних засобів української мови : навч. посіб. / ЗДУ. Запоріжжя : ЗДУ, 2002. $351 \mathrm{c.}$

27. Шиловский В. И. Проблема разграничения экспрессивности и эмотивности как семантических категорий стилістики. Проблемы семасиологии и лингвостилистики. 1975. Вып. 2. С. 115-127.

28. Grosse E. U. Text und Kommunikation : Eine ling. Einführung in die Funktionen der Texte. Stuttgart : Kohlhammer, 2006. 164 s.

29. Jakobson R. Linguistique et théorie de la communication. Essais de linguistique générale: Les fondations du langage. P. : Editions de Minuit, 1980. P. 87-99. 